\title{
Impact Implementation of Fiscal Decentralization and Regional Government Performance on the Accountability of Financial Reporting in Kupang Regency
}

\author{
Nonce.F. Tuati, D. W.Manuain, S.Samadara \\ \{nonc3tuati@yahoo.com,dece0169@gmail.com, selfisamadara@gmail.com\} \\ Politeknik Negeri Kupang, Indonesia
}

\begin{abstract}
This study aims to empirically prove the influence of Fiscal Decentralization, and the Performance of Local Government Organizations on the Financial Reporting Accountability of the Kupang Regency Regional Government. The sample used in this study was Judgment Sampling with a population of civil servants in the Revenue, Financial Management and Asset Management District of Kupang Regency. The method of data analysis uses multiple linear regression analysis using Statistical Package for the Social Sciences (SPSS). The results showed that Fiscal Decentralization had no effect on the Accountability of Regional Government Financial Reporting and the Performance of Local Government Administration positively influenced the Accountability of Regional Government Financial Reporting. Simultaneous testing (together) proves that Fiscal Decentralization and the Performance of Local Government Organizations affect the Financial Accountability of the Regional Government of Kupang Regency.
\end{abstract}

Keywords: fiscal, decentralization, financial, reporting, accountability

\section{Introduction}

Decentralization is defined as a process of political, fiscal devolution and decision making from the central government to regional governments [1]. The transfer of power to local governments aims to improve the stability of the democratic system, increase effectiveness and efficiency, stimulate the formation of a local and national economic development base, increase government transparency and increase community involvement in decision making (Moisiu, 2013). Fiscal decentralization is defined as the transfer of expenditure and income functions from the central government to regional governments [2]. Liu, 2007 and Syahrudin (2006) have proven that fiscal decentralization produces economic benefits for the country such as increased growth rates, increased effectiveness and efficiency in resource management and increased community participation in decision making [3].

The implementation of fiscal decentralization raises various problems because regions have different capacities and capabilities in terms of finance, infrastructure availability and human resource capacity (Syahrudin, 2006). With fiscal decentralization there was a significant flow of funds from the central government to regional governments. Local governments are required to increase accountability in the management and financial reporting of their governments. Ideally fiscal decentralization can improve efficiency, effectiveness, transparency and accountability in the management of government finances (Moisiu, 2013). 
Fiscal decentralization must be supported by a mechanism of Good Public Governance or good governance. the main goal of implementing Good Governance in the government sector is to increase accountability, participation, transparency and public performance in government affairs [4]. In Indonesia, the implementation of governance with the pillars of transparency, accountability, effectiveness, efficiency has gone through various stages (Crawford, Hermawan, 2000). Good Governance requires that regional financial management and reporting must be accountable and transparent. UU no. 17 of 2003 concerning state finances which was then followed by Government Regulation No. 24 of 2005 which was perfected by PP No. 71 of 2010 concerning Government Accounting Standards (SAP) requires governments at every level both central and regional to prepare financial reports. This financial report will then be reviewed by the government's external auditor, the Supreme Audit Board (BPK) periodically. The preparation and examination of local government financial statements is a step to realize accountability in government financial reporting.

The impact of implementing fiscal decentralization has been widely studied, including: (i) the effect of fiscal decentralization on the level of corruption (Moisiu, 2013; Rinaldi, 2007, Saputra, 2012); (ii) the impact of fiscal decentralization on public service outcomes (Liu, 2007); and (iii) the economic impact of fiscal decentralization (Syahrudin, 2006). But as far as researchers' observations are, especially in the NTT context, there has been no research that directly looks at the relationship between fiscal decentralization and governance to the accountability of local government financial reporting. Investigating the relationship between fiscal decentralization and governance with accountability of local government financial reporting is important and interesting because fiscal decentralization is related to the flow of public funds that must be accounted for by their use and management returned to the public as the ultimate owner of the government.Based on the description above, the researcher feels it is necessary to conduct research on the Impact of Fiscal Decentralization Implementation and the Performance of Local Government Implementation on the Accountability of Financial Reporting of the Kupang Regency Government

\subsection{Formulation of the problem}

Based on the description above, the formulation of the problem in this study:

1. Does fiscal decentralization affect the financial reporting of the Kupang Regency government financial reporting

2. Does the Performance of Local Government Organizations affect the accountability of financial reporting of the Kupang District government

3. Does Fiscal Decentralization, Local Government Implementation Performance simultaneously influence the Accountability of the Kupang District Government Financial Reporting?

\section{Literature review}

\subsection{Definition of Regional Finance}

Government Regulation Number 105 of 2000 [5] concerning Management and Accountability of Regional Finances, in its general provision states that what is meant by regional finance is all regional rights and obligations in the context of administering regional governments which can be valued in money including all forms of regional wealth, within the 
framework of the Regional Revenue and Expenditure Budget. The form of the Accountability Report at the end of the fiscal year consists of:

1) APBD Calculation Report

2) APBD Calculation Note

3) Cash Flow Statement

4) Regional Balance Sheet is completed with an assessment based on the Renstra benchmark (article 38 PP Number 105 Year 2000)

\subsection{Fiscal Decentralization}

Fiscal decentralization can be defined in 3 ways (Syahrudin, 2006), namely: (i) release of responsibility from the central government to the region (deconcentration), (ii) delegation of authority; and (iii) devolution. According to [6] fiscal decentralization can briefly be interpreted as a process of budget distribution from higher levels of government to lower governments, to support the functions or tasks of government and public services in accordance with the many authorities in the field of government delegated. In Indonesia, the implementation of fiscal decentralization began in 2001 as stipulated in Law No. 22 of 1999 and Law No. 25 of 1999 which was simultaneously applied in all provinces in Indonesia. Administrative decentralization without being followed by fiscal and political decentralization will not be effective [7]. Fiscal decentralization is a major component of political decentralization because if it is not followed by the transfer of financial authority, the devolution of authority for other public service activities will not be effective (Syahrudin, 2006).

\subsection{Local Government Implementation Performance}

One mechanism for evaluating the implementation of governance in Indonesia is through the Evaluation of Local Government Arrangements (EPPD) as stipulated in Government Regulation No. 6 of 2008 concerning guidelines for evaluating the administration of local governments. Previously, the regional government was required to submit a report that was used as a mechanism for the accountability of the performance of regional government. Furthermore, in Government Regulation No.3 of 2007, accountability is carried out in the form of providing reports as follows: (i) LPPD to the Government, (ii) Accountability Statement (LKPJ) of the Regional Head to the DPRD; and (iii) ILPPD to the Community which regulates various aspects of governance that must be submitted in the report. EPPD is done by using the main source of LPPD which contains information about the implementation of local government for one fiscal year (PP Number 6 of 2008). The main purpose of the evaluation is to assess the performance of local government in an effort to improve performance for support the achievement of the objectives of regional autonomy based on principles Good Governance.EPPD includes Evaluation of the Performance of the Regional Administration (EKPPD), Evaluation of the Capability of the Implementation of Regional Autonomy (EKPOD), and Evaluation of the New Autonomous Region (EDOB).

\subsection{Accountability}

Decree of the Head of the State Administration Agency (LAN) No.589 / IX / 6 / Y / 99 in [8], accountability is interpreted as an obligation to provide accountability or to answer and explain the performance and actions of a person / legal entity / collective leader of an organization to parties who have the right / authority to ask for information or accountability. Therefore, the enactment of the regional autonomy law must be able to increase the innovative power of the local government to be able to provide accountability reports on regional 
financial management in terms of efficiency and effectiveness to the DPRD and the wider community. The quality of good governance is not only determined by accountability, transparency, community participation and the rule of law. However, the quality of good governance is also determined by other factors such as responsiveness, consensus orientation, equity efficiency, effectiveness and strategic vision. This is consistent with the characteristics of good governance according to UNDP and Word Bank.

The accountability dimensions that must be fulfilled by public organizations include:

1. Honesty Accountability and Legal Accountability, namely honesty accountability associated with avoiding misuse of power (abuse of power), while legal accountability is related to ensuring compliance with laws and other regulations required in the use of public funding sources.

2. Accountability Process that is related to whether the procedures that have been used in carrying out the task are good enough in terms of the adequacy of accounting information systems, management information systems and administrative procedures. Process accountability is manifested through the provision of public services that are fast, responsive, and inexpensive.

3. Program accountability is related to the consideration of whether the objectives set can be achieved or not and whether it has considered alternative programs that provide optimal results with minimal costs.

4. Accountability Policy that is related to the responsibility of the coach, board and supervisor of the policies taken.

Osborne (1992) in [9] states that accountability is aimed at finding answers to questions relating to what service, who, to whom, whose, who, and how. Questions that require answers include, among others, what must be accounted for, why should accountability be handed over, to whom responsibility is given, who is responsible for various parts of the activity in the community, whether accountability goes hand in hand with adequate authority, and so forth. The concept of service in accountability is inadequate, so it must be followed by the spirit of etherpreneurship to those who carry out accountan

\section{Purpose and benefits of research}

\section{Research purposes}

1. To prove empirically the influence of Fiscal Decentralization, on the accountability of financial reporting of the Kupang Regency government

2. To prove empirically the effect of the Government's Implementation Performance on the financial reporting accountability of the Kupang Regency government financial

\section{Benefits of Research}

1. Provide knowledge and insights about the effects of Fiscal Decentralization, on the accountability of financial reporting of the Kupang District government

2. Providing knowledge and insights about the influence of the effect of the performance of government operations on the accountability of financial reporting of the Kupang district government 


\section{Research methods}

\subsection{Research Subjects and Objects}

The subject of this research is the Kupang Regency Regional Revenue, Financial Management and Asset Service The object of this study is the effect of fiscal decentralization, Performance of Local Government Organizing Towards the Financial Reporting Accountability of the Kupang Regency Government.

\subsection{Data Types and Sources}

The data used in this study are primary data. This primary data was obtained through a survey method using a questionnaire to the head of department, secretary, head of subdivision, head of subdivision, head of office and staff at the Kupang Regency Regional Revenue, Financial Management and Asset Service.

\subsection{Method of collecting date}

The primary data obtained by the author in this study is to use a questionnaire, namely data collection techniques by giving a list of written questions to respondents. Questionnaire on fiscal decentralization, Local Government Implementation Performance and financial reporting accountability. Questionnaires were distributed by going to and distributing questionnaires directly to the Kupang District. Each questionnaire package consists of two parts that must be answered by the respondent by following the instructions contained in each section. The first part contains questions related to respondent demographic data which includes gender, education and position. The second part contains questions relating to fiscal decentralization, Local Government Implementation Performance and financial reporting accountability.

\subsection{Population and Sample}

The population used in this study were civil servants in the Kupang Regency Regional Office of Financial and Asset Management which consisted of department heads, division heads, subdivision heads, section heads and staff. The researcher uses Judgment Sampling in determining the sample, namely the type of non-random sample selection, the information obtained is generally adjusted to the objectives or research problems [10]Researchers only use a minimum of group IIIa staff, section heads, subdivision heads and department heads who use the accounting system in the implementation of financial management and regional assets as well as the head of the department as a sample, so the sample in this study was 31 people

\subsection{Operational Definition and Variable Measurement}

The research variable is basically everything in the form of whatever is determined by the researcher to be studied in order to obtain information about it, then conclusions are drawn [11]. There are three variables used in this study, namely Fiscal Decentralization (variable $\mathrm{X} 1$ ), Local Government Implementation Performance (variable X2), as an independent variable and Financial Reporting Accountability (variable Y) as the dependent variable. 


\section{$5 \quad$ Research result}

\subsection{The Effect of Fiscal Decentralization on the Financial Accountability of the Kupang District Government}

Hypothesis test results from this study indicate that fiscal decentralization, variable X1 has no effect on financial accountability. The test results show that the value of tcount $<$ ttable $(-1.487<2.0457)$ with a significance of $0.169(\mathrm{P}>0.05)$. As such, Ho was accepted and rejected $\mathrm{Ha}$ and it can be stated that fiscal decentralization had no effect on the financial accountability of the Kupang District Government. This shows that fiscal decentralization has no effect on financial reporting accountability. The purpose of implementing fiscal decentralization is to increase regional independence so that it can finance regional development activities in order to improve the quality of public services. Fiscal decentralization is implemented because local governments know more about the priority needs of their own regions than the central government. This makes financing or expenditure carried out more efficiently and more accountably. However, the results found in this study indicate that fiscal decentralization has no effect on the financial reporting accountability of the local government of Kupang Regency. This may be due to the policy of fiscal decentralization that has not been fully met and implemented properly. The form and form of fiscal decentralization in Indonesia has only been distributed on the expenditure side, funded mainly through funds transfers to the regions to spend funds according to the needs of each region. While fiscal decentralization for the revenue side has not been implemented in a real way where the central government still controls the tax base in large amounts, while the district / city government still manages taxes in a relatively small amount due to restrictions on autonomy from the revenue side. The limitation of the government to increase regional revenue makes the government less optimal in carrying out regional development activities or public services.

5.2 The Effect of Performance of Local Government Organizations on the Financial Accountability of the Regional Government of Kupang Regency

The test results show the value of the Performance of Local Government Implementation, variable (X2) is 4,158 positive direction. This shows that the value of tcount $>$ ttable $(4.054>2.0432)$ with a significance of $0.000(\mathrm{P}<0.05)$. The test results show that the value of tcount $<$ ttable $(0.917<2.0347)$ with a significance of 0.327 ( $\mathrm{P}>0.05)$. Thus, Ho is rejected and accepts $\mathrm{Ha}$ and it can be stated that the Performance of the Regional Government Implementation affects the financial accountability of the Regional Government of Kupang Regency.

5.3 The Effect of Fiscal Decentralization, Performance of Local Government Implementation on the Accountability of the Kupang Regency Government's Financial Reporting.

The results of this study prove that there is an influence of fiscal decentralization, the Performance of Local Government Organizations Towards the Financial Reporting Accountability of the Kupang Regency Government. The results of the significance of the F test in this study amounted to $0.005(<0.05)$ so that the third hypothesis in this study was accepted. This hypothesis is also accepted because the F value is greater than F table $(5,574>$ 2.76. The acceptance of this hypothesis is also because the Fcount value is greater than Ftable, 
therefore it can be concluded that fiscal decentralization, the Performance of Local Government Organizations (simultaneously) affect the financial accountability of the local government of Kupang Regency. The results of this study carry the implication that to increase accountability Financial reporting of the Kupang district government, is required to carry out fiscal decentralization, implement the Performance of Local Government Implementation properly. Accountability of government financial reporting can be achieved if the government improves Local Government Implementation Performance can be interpreted as an efficient public service, a reliable control system, a government that is accountable to the public If the government has improved the Performance of Local Government Implementation well, then financial reporting accountability will also increase.

\section{Conclusion}

1. Fiscal Decentralization has no effect on Government Financial Accountability Kupang Regency Area.

2. The Performance of Local Government Organizations influences Accountability Financial District Government of Kupang Regency.

3. Fiscal Decentralization, Simultaneous Performance of Local Government Together) influences the Financial Accountability of the Regional Government of Kupang Regency.

\section{Suggestion}

1. Fiscal decentralization, Regional Government Implementation Performance needs to be better implemented in the Kupang District government in order to increase the financial accountability of the Kupang Regency regional government. If in terms of governance in the local government is good, the vision and mission and policies in the local government of Kupang Regency will be implemented well and can be achieved.

2. For further research can be done by adding several other independent variables, such as budget goals and objectives.

\section{References}

[1]Moisiu, Alexander. 2013. Dezentralizations and The Increased autonomy in Local Goverments, Procedia-Social and Behavioral Science, pp.459-463.

[2]Syahrudin. 2006. Desentralisasi Fiskal : Perlu Penyempurnaan Kebijakan dan Implementasi Yang Konsisten.

[3]Liu, Chih hung (2007). What Type of Fiscal Decentralization System has better Performance. School of Public Policy

[4]Kapucu, Naim (2009), New Public Management and Governance Perspectives in Understanding Public Management, Public Administration Review,

[5]Undang-undang NO. 33 tahun 2004 tentang Perimbangan Keuangan antara Pemerintah Pusat dengan Pemda

[6]Mahmudi. 2007. Manajemen Kinerja Sektor Publik. UPP STIM YKPN. Yogyakarta.

[7] Gideon, Jasmine. 2001. The Decentralization of Primary Health Care Delivery In Chile. Public Administration and Development.

[8] Bastian, Indra. (2006). Akuntansi Sektor Publik: Suatu Pengantar. Jakarta: Erlangga

[9] Mardiasmo. 2009. Akuntansi Sektor Publik. Andy Offset. Yogyakarta 
[10] Sekaran, Uma. (2006) Research Methods For Business : A Skill-Building Approach. John Wiley and Sons Inc, New York

[11] Sugiyono. 2012. Metode Penelitian Dan Bisnis. Bandung : Alfabeta. 